\title{
ANALISA KEBIJAKAN ANGGARAN DALAM PENGENDALIAN PENCEMARAN LINGKUNGAN AKIBAT OPERASIONAL PERTAMBANGAN EMAS SKALA KECIL (PESK) DI KABUPATEN XYZ
}

\author{
ROSLIANA $^{1}$ \\ Universitas Islam Indragiri \\ Email: r.rosliana@gmail.com \\ ROBERTA ZULFHI SURYA \\ Universitas Islam Indragiri \\ Email: robertazulfhi@yahoo.co.id \\ GERHANA ADJIE \\ STIE Indragiri, Rengat \\ Email: gerhanaadjie@stieindragiri.ac.id
}

\begin{abstract}
Artisanal Small-scale Gold Mining (ASGM) is the main support for the community's economy, but the use of mercury in the gold amalgamation process has implications for environmental damage. This study aims to determine budgeting policies in controlling environmental pollution due to ASGM operations and to mapping challenges and opportunities to provide recommendations for future improvements. Governments from various levels (National and Sub-National) have strengthened the legal framework by issuing several regulations to address the problem of mercury pollution. In a period of 5 years $(2015-2019)$ the XYZ District Government allocated a budget of IDR. 781.410,000,- for controlling environmental pollution due to ASGM operations. This study recommends using the ecological fiscal transfer mechanism from the National budget and collaborating with International Institutions (i.e. UNDP, World Bank, etc.) to solved mercury pollution solutions.
\end{abstract}

Keywords: Budget, Policy, Development Planning, Artisanal Small-Scale Gold Mining

\section{ABSTRAK}

Pertambangan Emas Skala Kecil (PESK) sebagai penopang utama perekonomian masyarakat, namun penggunaan merkuri pada proses amalgamasi emas berimplikasi pada kerusakan lingkungan. Penelitian ini bertujuan untuk mengetahui kebijakan penganggaran dalam pengendalian pencemaran lingkungan hidup akibat operasional PESK serta memetakan tantangan dan peluang untuk memberikan rekomendasi untuk perbaikan kedepannya. Pemerintah dari berbagai level telah melakukan penguatan kerangka hukum dengan menerbitkan beberapa regulasi untuk mengatasi permasalahan pencemaran akibat merkuri. Dalam kurun waktu 5 tahun (2015 - 2019) Pemerintah Kabupaten XYZ mengalokasikan anggaran sebesar Rp. 781.410.000,- untuk pengendalian pencemaran lingkungan hidup akibat operasional PESK. Penelitian ini merekomendasikan untuk menggunakan mekanisme ecological fiscal transfer dari APBN dan bekerjasama dengan lembaga internasional dalam menyelesaikan solusi pencemaran akibat merkuri.

Kata Kunci: Anggaran, Kebijakan, Perencanaan Pembangunan, Pertambangan Emas Skala Kecil

\section{PENDAHULUAN}

Berdasarkan Undang-Undang Nomor 23 Tahun 2014 tentang Pemerintahan Daerah, Pemerintah Daerah telah diberikan kewenangan untuk mengatur dan mengurus sendiri urusan pemerintahan menurut asas otonomi dan tugas pembantuan dalam rangka meningkatkan kesejahteraan masyarakat dengan memperhatikan prinsip demokrasi, pemerataan, keadilan, keistimewaan dan kekhususan serta keragaman daerah dalam kerangka Negara Kesatuan Republik Indonesia. Sejalan dengan kondisi dan perkembangan masyarakat yang menuntut adanya transparasi dan akuntabilitas dalam penyelenggaran pemerintahan daerah, dan untuk menciptakan pemerintahan yang bersih, bertanggungjawab serta mampu menjawab tuntutan perubahan secara efektif dan efisien sesuai dengan prinsip tata pemerintahan yang baik, maka diterbitkanlah Peraturan Pemerintah Nomor 3 Tahun 2007 tentang Laporan Penyelenggaraan Pemerintahan Daerah kepada Pemerintah, Laporan Keterangan Pertanggungjawaban Kepala Daerah kepada Dewan Perwakilan Rakyat Daerah, dan Informasi Laporan Penyelenggaraan Pemerintahan Daerah kepada Masyarakat (Suwandi, 2015).

Aktivitas Ekonomi mikro masyarakat lokal yang memamfaatkan sumberdaya alam yang melimpah berimplikasi terhadap kerusakan lingkungan hidup. Seperti Illegal Logging, pertambangan emas menggunakan merkuri, alih fungsi lahan hutan menjadi perkebunan kelapa sawit secara sporadis, praktek perikanan yang tidak berkelanjutan dan beracam aktivitas pemanffaatan sumberdaya alam yang tidak memperhatikan aspek sustainability. Kabupaten XYZ memiliki kekayaan alam yang bersumber dari pertambangan emas skala kecil sehingga sektor ini cukup menggerakkan ekonomi lokal karena sebagai mata pencaharian sebagian besar masyarakat tempatan. Dikarenakan aktivitas ini tidak mengantongi izin dari pemerintah dan menggunakan merkuri pada proses produksinya sehingga dianggap ilegal meskipun sektor ini sangat krusial pada aktivitas perekonomian. 


\section{TINJAUAN PUSTAKA}

\subsection{Proses Penyusunan Rencana Dan Anggaran Pemerintah}

Proses penyusunan anggaran dalam penelitian ini digunakan untuk mengetahui proses penyusunan anggaran di tingkat kabupaten yang dimulai dari penyusunan anggaran dengan cara mendeskripsikan keadaan yang nyata terjadi serta pandangan teori yang terkait. Permendagri No.13 Tahun 2006 yang merupakan penjabaran PP No. 58 Tahun 2005 telah mengatur secara rinci mekanisme, proses,dan prosedur penyusunan penganggaran tahunan daerah, termasuk di dalamnya Rencana Kerja Pemerintah Daerah (RKPD), Kebijakan Umum Anggaran-Prioritas Plafond Anggaran Sementara (KUA-PPAS), Rencana Kerja Anggaran Organisasi Perangkat Daerah (RKA-OPD), Rencana Anggaran Pembangunan Belanja Daerah (RAPBD) dan Anggaran Pembangunan Belanja Daerah (APBD). Mengingat Rencana Pembangunan Jangka Menengah Daerah (RPJMD) dan Rencana Strategis Organisasi Perangkat Daerah (Renstra OPD) perlu sedemikian rupa sehingga mudah diterjemahkan ke dalam rencana dan penganggaran tahunan daerah yang diatur dalam Permendagri No. 13Tahun 2006. Hal ini juga bermakna bahwa RPJMD dan Renstra OPD harus mencerminkan kerangka penganggaran yang diatur dalam Permendagri tersebut. Untuk itu, renstra OPD perlu menggunakan kerangka fungsi, urusan wajib, dan urusan pilihan pemerintah daerah dalam menganalisis isu strategis, merumuskan strategi, kebijakan, dan menetapkan prioritas programnya, setiap program perlu mempunyai tolok ukur dan target kinerja capaian program yang jelas. Untuk memastikan anggaran akuntabel, tepat sasaran dan bermanfaat, Undang - Undang No. 25 Tahun 2004 mewajibkan penganggaran keuangan daerah memiliki sistemasi dan keterkaitan antar document perencanaan dalam skema berikut.

\section{Gambar 2.1}

Keterkaitan RPJPD, RPJMD dan APBD dalam keuangan daerah

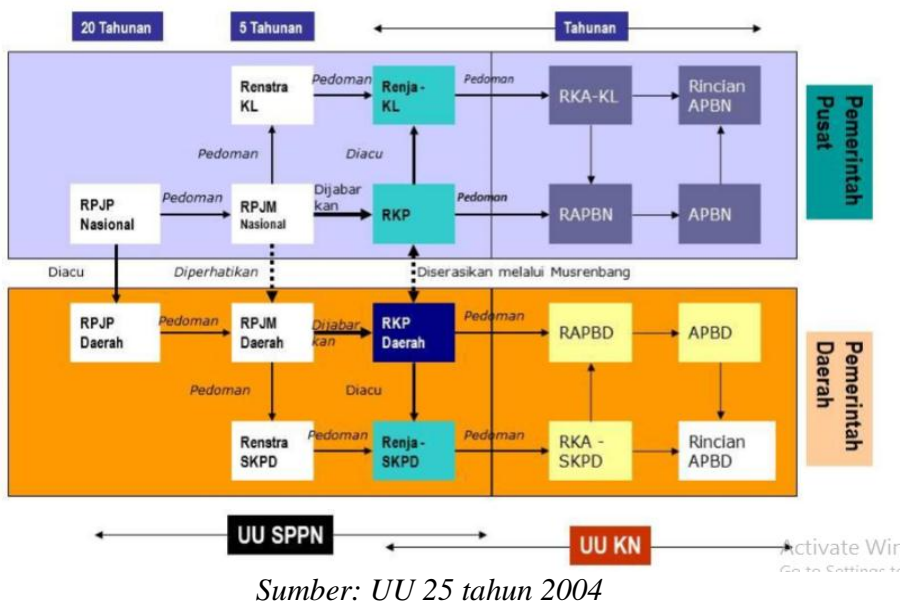

\subsection{Pertambangan Emas Skala Kecil (PESK)}

Kegiatan penambangan emas tradisonal di Indonesia dicirikan oleh penggunaan teknik eksplorasi dan eksploitasi yang sederhana dan murah. Adanya kegiatan penambangan emas ini, sering menimbulkan masalah yang menimpa kelompok masyarakat setempat yang pada umumnya hidup dalam kemiskinan dan tidak memiliki pendidikan cukup. Mereka memanfaatkan sumber daya alam yang ada seperti menambang emas yang diolah dengan cara yang sederhana. Inilah yang disebut dengan kelompok tambang emas skala kecil, tambang emas rakyat atau tambang emas tradisonal atau Penambang Emas Skala Kecil (Banunaek, 2016).

Metode amalgamasi merupakan metode yang sangat umum ditemui pada sektor PESK. Proses amalgamasi yaitu proses pengikatan logam emas dari bijih tersebut dengan menggunakan merkuri (Hg) dalam tabung yang disebut sebagai gelundung. Amalgam merupakan proses ekstraksi emas yang paling sederhana dan murah. Secara umum PESK menggunakan cara amalgamasi sebagai berikut (Suyono, 2011):

Gambar 2.2

Pengolahan Emas Tradisional Cara Amalgamasi

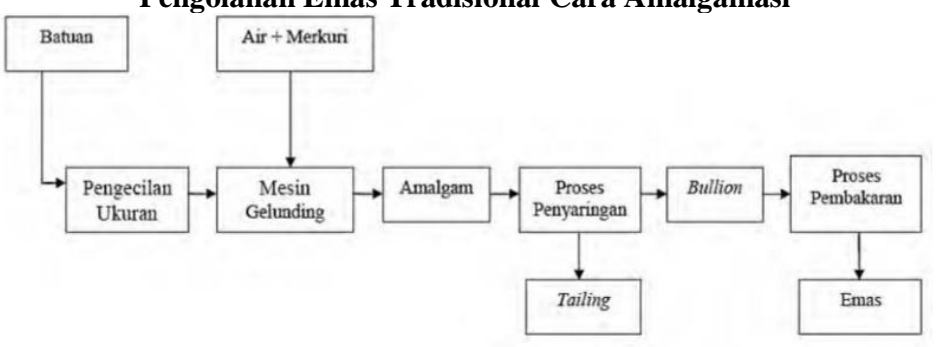

Sumber: Suyono (2011)

Rosliana-Surya-Adjie, Analisa Kebijakan Anggaran Dalam Pengendalian Pencemaran Lingkungan Akibat Operasional Pertambangan Emas Skala Kecil (PESK) di Kabupaten XYZ 


\section{METODOLOGI PENELITIAN}

Metode yang digunakan dalam penelitian ini adalah pendekatan kualitatif dengan metode studi kasus. Studi kasus merupakan salah satu jenis penelitian kualitatif, dimana peneliti melakukan ekplorasi secara mendalam terhadap program, kejadian, proses, aktivitas terhadap satu orang atau lebih. Teknik pengumpulan data yang digunakan adalah melalui pengamatan/observasi (observation), desk review terhadap dokumen terkait, wawancara mendalam (indepth interview) dan dokumentasi (documentation) (Sugiyono, 2015)

Waktu pelaksanaan penelitian yaitu selama bulan Januari sampai Februari 2021, dikarenakan anggaran daerah merupakan rahasia Negara, dengan demikian objek penelitian di beri nama Kabupaten XYZ. Penelitian di aksanakan di Kabupaten XYZ dengan mereview dokumen terkait anggaran pembangunan belanja daerah meliputi:

1. Rencana pembangunan jangka panjang

2. Rencana pembangunan jangka menengah

3. Rencana tata ruang wilayah

4. Rencana kerja pemerintah daerah 5 tahun terakhir

Berdasarkan data tersebut di atas, nantinya akan digunakan sebagai input dalam melakukan analisis terhadap anggaran pengelolaan lingkungan akibat operasional PESK. Secara umum, jenis penelitian yang dilakukan adalah penelitian kualitatif dengan menganalisa regulasi dan tantangan yang dihadapi sehingga menemukan rekomendasi yang berpeluang sebagai alternatif solusi kebijakan anggaran pengelolaan pencemaran lingkungan akibat operasional PESK.

\section{HASIL PENELITIAN DAN PEMBAHASAN}

\subsection{Penegakan Hukum Dan Kerusakan Lahan}

Penegakan hukum lingkungan pemulihan kualitas lingkungan hidup merupakan salah satu fokus pemerintah Kabupaten XYZ dalam rangka meningkatkan kondisi kualitas lingkungan hidup kedepannya. Hal ini berdasarkan pertimbangan kondisi lingkungan saat ini dibeberapa tempat terjadi penurunan kualitas lingkungan. Penurunan kualitas lingkungan antara lain terlihat pada kondisi kualitas air sungai, kondisi lahan yang kritis. Banyak faktor yang menyebapkan terjadinya penurunan kualitas lingkungan, dalam beberapa kasus di Kabupaten XYZ terhadap aduan masyarakat bahwa pencemaran air sungai disebapkan karena limbah industri baik besar maupun kecil walaupun untuk pembuktiannya harus dilalui kajian uji laboratorium. Selain itu banyak pula kasus-kasus penurunan kualitas lingkungan disebabkan karena penambangan emas tanpa izin terhadap hal tersebut menjadi dominan dari beberapa kasus permasalahan lingkungan di Kabupaten XYZ karena kerusakan yang terjadi tampak langsung berupa perubahan warna air menjadi keruh dan lahan menjadi kritis. Walaupun pemerintah daerah dan aparat telah melaksanakan penegakan hukum lingkungan terhadap beberapa kasus penambangan emas tanpa izin, namun pada prakteknya aktifitas PESK masih tetap ada. Secara umum pada tahun 2015 jumlah lahan kritis yang ada di Kabupaten XYZ yang disebapkan oleh PESK yang terdata di 7 kecamatan mencapai 10.893,86 Hektar.

\subsection{Kerangka Kebijakan, Tantangan Dan Peluang}

Berdasarkan Rencana Pembangunan Jangka Panjang (RPJPD) Kabupaten XYZ, Rencana Pola Ruang (Geospasial) Sektor Pertambangan dalam Arah Pemanfaatan Ruang (Geospasial) / Indikasi Program pada rentang tahun 2015 - 2020 direncanakan pengembangan potensi pertambangan emas di beberapa kecamatan mengingat daerah tersebut sangat kaya akan sumberdaya emas yang ditambang secara primer yang telah diberlangsung secara turun temurun sejak zaman kolonial Belanda.

Rencana Pembangunan Jangka Menengah Daerah (RPJMD) merupakan satu tahapan rencana pembangunan yang harus disusun oleh semua tingkatan pemerintahan, baik pemerintah pusat maupun pemerintah daerah, sebagaimana yang diamanatkan dalam Undang-undang Nomor 25 Tahun 2004 tentang Sistem Perencanaan Pembangunan Nasional. Sesuai dengan Undang-undang Nomor 25 Tahun 2004 tentang Sistem Perencanaan Pembangunan Nasional bahwa Rencana Pembangunan Jangka Menengah Daerah (RPJMD) disusun dengan maksud untuk menjabarkan Visi dan Misi Kepala Daerah dalam jangka waktu lima tahun, kemudian RPJMD tersebut harus menggambarkan rencana pembangunan yang terukur baik anggaran maupun target capaian yang diinginkan dalam rangka melakukan perubahan dari suatu kondisi kepada kondisi yang lebih baik.

Isu merkuri menjadi isu Internasional dimana Indonesia berkomitmen dengan meratifikasi konvensi minamata melalui Undang-undang nomor 11 tahun 2017. Selanjutnya Presiden menerbitkan Peraturan Presiden nomor 21 tahun 2019 tentang Rencana Aksi Nasional Pengurangan dan Penghapusan Merkuri. Manifestasi dari Perpres tersebut Menteri Lingkungan Hidup dan Kehutanan menerbitkan Peraturan Menteri Lingkungan Hidup dan Kehutanan nomor P.81/MENLH/SETJED/KUM.1/10/2019. Isu PESK dan Merkuri menjadi salah satu misi daerah sehingga Kabupaten XYZ turut berkomitmen dalam pengurangan merkuri dengan menerbitkan Peraturan Bupati nomor 72 tahun 2020 tentang Rencana Aksi Daerah Pengurangan dan Penghapusan Merkuri. 
Berdasarkan desk review terhadap dokumen RPJMD 2 periode kepala daerah dan visi-misi kepala daerah terpilih pada Pilkada 2020 lalu, terlihat secara jelas komitmen yang baik dari pihak pemerintah dalam Pengendalian Dampak Kerusakan Lingkungan pada sektor Pertambangan Emas Skala Kecil di Kabupaten $\mathrm{XYZ}$

Tabel 4.1

Indikator Kinerja Daerah berkaitan dengan Pengendalian Dampak Lingkungan sektor PESK

\begin{tabular}{|c|c|c|c|}
\hline Periode RPJMD & $\begin{array}{c}\text { Indikator yang berkaitan dengan Pengendalian Dampak } \\
\text { Lingkungan Sektor PESK }\end{array}$ & Tahun ke- 0 & $\begin{array}{l}\text { Tahun ke- } \\
5\end{array}$ \\
\hline $2011-2016$ & $\begin{array}{l}\text { Menurunnya Cakupan Kasus pencemaran lingkungan yang } \\
\text { ditangani }(\%)\end{array}$ & $100 \%$ & $100 \%$ \\
\hline $2016-2021$ & $\begin{array}{l}\text { Luas Kerusakan Lahan Akibat PETI/ Penambangan Emas } \\
\text { Tanpa Izin ( Ha) }\end{array}$ & 7.951,93 Ha & $6901,27 \mathrm{Ha}$ \\
\hline $\begin{array}{ll}2021-2026 \\
\text { Visi-Misi } \\
\text { terpilih }\end{array}$ & $\begin{array}{l}\text { Pencegahan PETI dan pengelolaan kawasan terdampak PETI } \\
\text { sehingga bernilai ekonomis bagi masyarakat }\end{array}$ & \multicolumn{2}{|c|}{$\begin{array}{l}\text { Belum didefinisikan karena } \\
\text { sedang penyusunan RPJMD }\end{array}$} \\
\hline
\end{tabular}

Sumber: Dokumen RPJMD Kabupaten XYZ

Penyusunan Rancangan APBD Proses perencanaan dan penyusunan APBD, mengacu pada PP Nomor 58 Tahun 2005 tentang Pengelolaan Keuangan Daerah, secara garis besar sebagai berikut: 1) penyusunan rencana kerja pemerintah daerah; 2) penyusunan rancangan kebijakan umum anggaran; 3) penetapan prioritas dan plafon anggaran sementara; 4) penyusunan rencana kerja dan anggaran OPD; 5) penyusunan rancangan perda APBD; dan 6) penetapan APBD Penyusunan APBD didasarkan pada perencanaan yang sudah ditetapkan terlebih dahulu, mengenai program dan kegiatan yang akan dilaksanakan. Berdasarkan Dokumen APBD dalam kurun waktu 5 tahun, anggaran untuk Pengendalian Dampak Kerusakan Lingkungan Akibat PESK sebagai berikut:

Tabel 4.2

Indikator Kegiatan dalam Pengendalian Dampak Lingkungan sektor PESK.

\begin{tabular}{|l|l|l|}
\hline Tahun & Indikator Kegiatan & Pagu APBD \\
\hline 2015 & Pengendalian Dampak Kerusakan Lingkungan Akibat PETI & Rp. 300.000 .000 \\
\hline 2016 & Pengendalian Dampak Kerusakan Lingkungan Akibat PETI & Rp. 176.510 .000 \\
\hline 2017 & Pengendalian Dampak Kerusakan Lingkungan Akibat PETI & Rp. 135.000 .000 \\
\hline 2018 & Pengendalian Dampak Kerusakan Lingkungan Akibat PETI & Rp. 67.600 .000 \\
\hline 2019 & Pengendalian Dampak Kerusakan Lingkungan Akibat PETI & Rp. 102.300 .000 \\
\hline
\end{tabular}

Sumber: Dokumen RKPD Kabupaten XYZ 5 tahun terakhir

Dalam kurun waktu 5 tahun (2015 - 2019) anggaran yang dialokasikan sebesar Rp. 781.410.000,-., angka ini dinilai sangat minim untuk mengatasi kerusakan lingkungan akibat operasional PESK di Kabupaten XYZ. Apablia ditilik penjabaran anggaran, pada umumnya anggaran dialokasikan untuk kegiatan Sosialisasi dan patroli dengan penjabaran belanja pegawai, belanja makan-minum, belanja honor narasumber, belanja alat tulis, belanja cetak dan penggandaan, dan belanja perjalanan Dinas.

Fakta dan data di atas terkait penganggaran isu lingkungan tidak menjadi prioritas utama sehingga kebijakan dan penganggaran untuk sektor PESK di Kabupaten XYZ sangat minim dan rentan rasionalisasi. Sejalan dengan publikasi Kementrian Bappenas tahun 2011 yang berjudul Kajian Kualitas Belanja APBD menerangkan bahwa indikator lingkungan berada di bawah isu kesehatan, pendidikan, ekonomi, infrastruktur, dan kemiskinan. Berdasarkan kajian terhadap PPAS anggaran untuk isu lingkungan hidup berada pada urutan prioritas ke-8 dan prioritas ke-9 (Bappenas, 2011)

Tantangan lain dimasa Pandemi Covid-19 mengubah segala sistem kehidupan termasuk penganggaran. Pemerintah melalui Keputusan Bersama Menteri Dalam Negeri dan Menteri Keuangan RI nomor 119/2813/SJ-Nomor 177/KMK.07/2020 tanggal 19 April 2020 tentang Percepatan Penyesuaian APBD 2020 dan dalam rangka Penanganan Covid-19 serta Pengamanan Daya Beli Masyarakat dan Perekonomian Nasional juga mempengaruhi kinerja keuangan kegiatan yang berkaitan dengan lingkungan hidup.

Dikarenakan isu lingkungan hidup tidak menjadi prioritas utama dalam APBD, Mekanisme Dana Alokasi Umum (DAU) memiliki potensi menjadi sumber pendanaan lingkungan dan kehutanan melalui mekanisme ecological fiscal transfer. Mekanisme ecological fiscal transfer diwujudkan melalui penambahan pagu alokasi DAU untuk kepentingan pelestarian lingkungan dan kehutanan serta menambahkan indikator lingkungan hidup dan kehutanan dalam formulasi eksisting DAU (Haryono, 2015). Berhubungan dengan tupoksi bidang kehutanan berada dalam koordinasi pada level provinsi sedangkan indikator pengendalian pencemaran lingkungan masih berada dalam wewenang Kabupaten/Kota. Dengan demikian skema ecological fiscal transfer dapat dijadikan alternatif peningkatan anggaran pengelolaan lingkungan hidup akibat operasional PESK.

Faktor lain isu merkuri mejadi isu internasional dan komitmen pemerintah Republik Indonesia dalam pengurangan dan penghapusan merkuri. Peluang lain untuk dukungan anggaran dan kegiatan pengendalian pencemaran lingkungan hidup akibat merkuri dapat mengundang peran serta aktif dari Lembaga Internasional seperti World Bank dan United Nation Development Programme 


\section{KESIMPULAN DAN SARAN}

5.1 Kesimpulan

Kesimpulan dari penelitian ini adalah sebagai berikut:

1. Secara kebijakan, berdasarkan visi-misi jangka menengah daerah terlihat komitmen yang baik dari pihak pemerintah dalam pengendalian dampak kerusakan lingkungan akibat operasional PESK.

2. Anggaran untuk pengendalian dampak kerusakan lingkungan operasional PESK di Kabupaten XYZ sangat minim dan rentan rasionalisasi.

3. Anggaran merupakan dokumen publik sebagai komitmen eksekutif dan kesepakatan legislatif atas penggunaan dana publik. Dari sisi politik anggaran, anggaran untuk sektor lingkungan hidup khususnya pengendalian dampak kerusakan lingkungan akibat operasional PESK tidak menguntungkan secara politis.

4. Penganggaran program pengendalian dampak kerusakan lingkungan akibat operasional PESK tidak melalui pertimbangan Perencanaan Penganggaran Responsif Gender (PPRG);

5. Recovery COVID 19 sangat berdampak pada penganggaran pada sektor lingkungan hidup.

\subsection{Saran}

Setelah dilakukan beberapa analisa terhadap data dan informasi terkait, maka penelitian ini memberikan saran untuk kedepannya adalah:

1. PESK merupakan aktivitas ekonomi yang menyangkit dengan hajat hidup masyarakat tempatan, disarankan kepada pihak terkait untuk melalukan pendampingan proses pertambangan emas tanpa merkuri serta membantu komunitas penambang untuk mempersiapkan Izin Pertambangan Rakyat (IPR). Wilayah Pertambangan Rakyat (WPR), Analisis Dampak Lingkungan (AMDAL) serta perizinan terkait lainnya sehingga aktivitas PESK tidak lagi melanggar hukum.

2. Disarankan kepada Pemerintah Daerah untuk memasukkan agenda ecological fiscal transfer ke dalam penyusunan Rencana Kerja Pemerintahan Daerah (RKPD).

3. Penelitian ini belum menilai pada realisasi APBD dalam dokumen APBD Pertanggungjawaban dan Laporan Kinerja Pertanggung Jawaban (LKPj), disarankan penelitian selanjutnya untuk menelaah sampai pada realisasi.

\section{DAFTAR PUSTAKA}

Banunaek, Z.A.. 2016. Pencemaran Merkuri di Lahan Pertambangan Emas Rakyat Dan Strategi Pengendaliannya. Thesis Magister Teknik Lingkungan ITS Surabaya

Bappenas, 2011. Kualitas Belanja APBD. Direktorat Otonomi Daerah, Deputi Bidang Pengembangan Regional dan Otonomi Daerah

Haryono. 2015. Studi Ecological Fiscal Transfer sebagai Potensi Pendanaan Lingkungan di Daerah. Jurnal Ilmu Sosial dan Ilmu Politik Volume 18, Nomor 3, Maret 2015 (252-266).

Sugiyono. 2015. Metode Penelitian dan Pengembangan ALFABETA: Bandung.

Sugiyono. 2015. Memahami Penelitian Kualitatif. ALFABETA: Bandung.

Suwardi. 2015. Analisis Proses Penyusunan Anggaran Pendapatan Dan Belanja Daerah (APBD) (Studi di Dinas Pendidikan Provinsi Sumatera Utara). Jurnal Administrasi Publik ISSN: 2088-527x, JAP Vol. 3 No. 2.

Suyono. A. 2011. Dampak Penggunaan Hg Pada Penambangan Emas Rakyat Terhadap Lingkungan. Tugas Akhir, Jurusan Teknik Lingkungan, Fakultas Teknologi Mineral, Universitas Pembangunan Nasional, Veteran, Yogyakarta

Undang-Undang Nomor 11 Tahun 2017 tentang Pengesahan Minamata Convention on Mercury

Undang-Undang Nomor 23 Tahun 2014 tentang Pemerintahan Daerah, Pemerintah Daerah.

Peraturan Pemerintah Nomor 3 Tahun 2007 tentang Laporan Penyelenggaraan Pemerintahan Daerah;

Keputusan Bersama Menteri Dalam Negeri dan Menteri Keuangan RI nomor 119/2813/SJ-Nomor 177/KMK.07/2020 tanggal 19 April 2020 tentang Percepatan Penyesuaian APBD 2020;

Peraturan Presiden nomor 21 tahun 2019 tentang Rencana Aksi Nasional Pengurangan dan Penghapusan Merkuri.

Peraturan Menteri Lingkungan Hidup dan Kehutanan menerbitkan Peraturan Menteri Lingkungan Hidup dan Kehutanan nomor P.81/MENLH/SETJED/KUM.1/10/2019 tentang pelaksanaan Peraturan Presiden nomor 21 tahun 2019 tentang Rencana Aksi Nasional Pengurangan dan Penghapusan Merkuri

Peraturan Bupati Kabupaten XYZ nomor 72 tahun 2020 tentang Rencana Aksi Daerah Pengurangan dan Penghapusan Merkuri 